\title{
Evidence for the Generation of Juvenile Granitic Crust During Continental Extension, Mineral Mountains Batholith, Utah
}

\author{
DREW S. COLEMAN ${ }^{1}$ AND J. DOUGLAS WALKER
}

Department of Geology, University of Kansas, Lawrence

\begin{abstract}
Field, chemical and isotopic data from the Miocene Mineral Mountains batholith in southwest Utah are consistent with the batholith being derived through differentiation of material recently separated from the lithospheric mantle, with little involvement of pre-Oligocene crust. The batholith ranges in composition and texture from diabase and gabbro to high-silica thyolite and granite and is distinctly calcalkaline in nature. Field evidence for anatexis of intermediate-composition Oligocene crust and magma mixing suggest that fractional melting and mixing were important processes during the evolution of the batholith. Major oxide and rare earth element data for the batholith are consistent with chemical evolution of the magma system being controlled by fractionation of homblende, plagioclase and sphene (all of which occur in restitic portions of Miocene migmatites exposed in the field area) during partial melting, and mixing between gabbro and granite. Isotopic data indicate a lithospheric mantle source for mafic rocks in the study area and, on the basis of field data and their similarity in isotopic composition, granitic rocks are interpreted to be derived indirectly from the same source during Basin and Range extension. Evolution of the granites is hypothesized to involve a series of partial melting steps, one of which is exposed in the batholith, which refine mantle-derived gabbros into high-silica rocks. Thus the Mineral Mountains batholith represents juvenile granitic material added to the crust during extension. This raises the possibility that extension may be an important granitic crust-forming event. Furthermore, this suggests that pure-shear igneous inflation of the crust by the mantle can be an important mechanism during extensional deformation. Data presented here indicate that fractional melting of young mafic crust may be an important process in the evolution of isotopically homogeneous intrusive suites which span a broad compositional range. Furthermore, the data support the idea that lithospheric mantle in the Great Basin region may be Proterozoic in age.
\end{abstract}

\section{INTRODUCTION}

Investigation of the evolution of the continental crust during extension is fundamentally important to understanding crustal genesis because evidence for continental rifting is observed throughout the geologic record. Extension-related magmatism is generally credited with remobilizing preexisting crust [cf. Eichelberger, 1978; Hildreth, 1981] and generating new mafic crust through underplating [cf. Gans, 1987; Johnson, 1991], with little or no generation of juvenile high-silica crust. However, recent work in Proterozoic "anorogenic" magmatic terranes, which are often interpreted to be extensional [Anderson, 1983; Bickford, 1988; Kay et al., 1989; Windley, 1989], has revealed that mantle separation ages and crystallization ages of some of these granitic rocks are very similar [Nelson, 1990; Bowring et al., 1991], suggesting that high-silica crust may evolve very quickly in extensional orogens. The remarkable similarity between the isotopic compositions of coeval rhyolitic and basaltic magmas erupted locally during Basin and Range extension in the western United States also suggests that the high-silica units may have been derived recently from the same source as the basaltic magmas, implying that the rhyolites represent young mantle differentiates, and thus juvenile crust [Johnson et al., 1990; Tegtmeyer, 1990; Johnson, 1991]. The data for Proterozoic rocks and young rocks from the Basin and Range suggest that granitic liquids can evolve quickly from the mantle, a process that is generally considered to occur very indirectly over an extended period of time, involving a variety of tectonic settings [cf. Bickford, 1988].

${ }^{1}$ Now at Department of Geology, University of North Carolina, Chapel Hill,

Copyright 1992 by the American Geophysical Union

Paper number 92JB00653.

0148-0227/92/92JB-00653\$05.00
If intrusion of mantle-derived melts into the crust during extension is voluminous, then pure shear through igneous inflation may be the locally dominant mechanism of extension [Bohannon, 1986]. The possibility of igneous inflation is particularly enticing for the Basin and Range Province because the area has experienced extreme extension (locally 250-500\% [Miller et al., 1983; Gans, 1987; Wernicke et al., 1988, 1989]) over a very wide region ( $\left.25,000 \mathrm{~km}^{2}\right)$, yet it maintains a relatively thick crust $(-30 \mathrm{~km}$ [Prodehl, 1970, 1979]). This apparent paradox can be explained if crustal thickness has been maintained through the generation of juvenile crust. Gans [1987] suggested that significant amounts of mafic underplating during extension can account for the structural and geophysical nature of some extended areas, and Johnson et al. [1989, 1990] and Johnson [1991] suggested that large-volume silicic volcanic centers in the western United States may contain a significant fraction (30 to $>50 \%$ ) of mantle-derived material, consistent with this idea. Alternatively, if magmatic activity was dominated by remelting of preexisting crust, simple shear may be the mechanism of extension and crustal thickness may be maintained through lateral flow of middle [Wernicke, 1990] or lower [Block and Royden, 1990] crustal rocks.

The role of the mantle during continental rifting may be even more fundamental than accommodating deformation through inflation if the mantle is actively driving extension. Menzies [1989] argues for active upwelling of asthenospheric mantle in regions of high heat flow in the Basin and Range Province, and Perry et al. [1987] suggest that lithospheric sources may be sampled passively during initial phases of rifting along the Rio Grande rift, and that active upwelling of the asthenosphere eventually replaces the lithospheric mantle. Altematively, Fitton et al. [1988] showed that within the Basin and Range province, asthenospheric mantle sources were involved only in areas of maximum crustal thinning, implying that the mantle is sampled passively, and that the nature of the mantle source is dependent on the degree of extension.

In this study we investigate the petrology and chemistry of the Miocene Mineral Mountains batholith in Utah in order to under- 
stand the relative roles of the crust and mantle during extensional magmatism in the region. We examine the evolution of the magma system over approximately $25 \mathrm{Ma}$ of igneous activity and attempt to discern the nature of the mantle locally involved in magmatism, and the mechanism(s) of granitic crust formation in the range.

\section{Geologic Setring}

The Mineral Mountains batholith lies in southwest Utah, and comprises approximately $200 \mathrm{~km}^{3}$ of exposed Miocene granitic rocks (Figure 1). The northem and southem wall rocks of the batholith are Paleozoic sedimentary rocks, and the western wall rocks are $1725 \mathrm{Ma}$ gneisses [J. D. Walker and J. M. Bartley unpublished mapping, 1990,1991;Earl, 1957; Liese, 1957; Condie, 1960; Nielson et al., 1978, 1986; Sibbett and Nielson, 1980; Aleinikoffet al., 1987; Walker and Bartley, 1990; Coleman, 1991]. The southern end of the batholith is separated from Paleozoic and Mesozoic sedimentary rocks and Oligocene volcanic rocks by the Cave Canyon detachment fault [Nelson et al., 1986; Price and Bartley, 1990], which was interpreted to be a strand of the Sevier Desert detachment fault, mapped in the subsurface to the north of the Mineral Mountains (Figure 1) [Allmendinger et al., 1983; Von Tish et al., 1985; Barker, 1986; Price and Bartley, 1990; Walker and Bartley, 1990]. Nielson et al. [1986] concluded that the plutonic rocks were intruded during detachment faulting; however, Price and Bartley [1990] noted that 9-Ma rhyolite porphyry dikes interpreted by Nielson et al. [1986] to cut the Cave Canyon detachment are cut by cataclasites related to the detachment fault, indicating that some brittle deformation occurred after emplacement of the pluton. Intrusive rocks correlated with the Mineral Mountains batholith occur in the hanging wall of the Cave Canyon detachment in the southern part of the Mineral Mountains and in the Star Range, Rocky Range and Beaver Lake Mountains to the west (Figure 1) [Coleman, 1991; D. E. Price, J. M. Bartley and J. D. Walker, unpublished mapping. 1990, 1991].

Geochronologic data demonstrate that the Mineral Mountains batholith intruded between 25 [Aleinikoff et al., 1987] and $9 \mathrm{Ma}$ [Nielson et al., 1986] and that intrusion took place in at least four distinct episodes. The bulk of the exposed intrusive rocks (>80\%) were emplaced between 18 and 16 Ma [Coleman, 1991]. Intrusion of the early phases of the pluton does not appear to be synchronous with substantial extensional deformation; however, the emplacement of dikes at $9 \mathrm{Ma}$ occurred during a period of significant regional detachment faulting and uplift of the range [Nielson et al., 1986]. Hornblende barometry for rocks intruded between 25 and $16 \mathrm{Ma}$ indicate that they all intruded at pressures of 2.0 to $2.5 \mathrm{kbar}$, consistent with the idea that most uplift occurred after emplacement of the batholith [Coleman, 1991]. The Mineral Mountains area has remained magmatically active and was the sight of voluminous Quatemary volcanism [Lipman et al., 1978] and continues to be a geothermal "hot spot." With the exception of minor 8 to 9-Ma rhyolite flows [Evans and Stevens, 1982], there are no known extrusive equivalents to the intrusive rocks exposed in the Mineral Mountains.

The batholith ranges in composition and texture from diabase and gabbro to high silica rhyolite and granite, with quartz monzo-

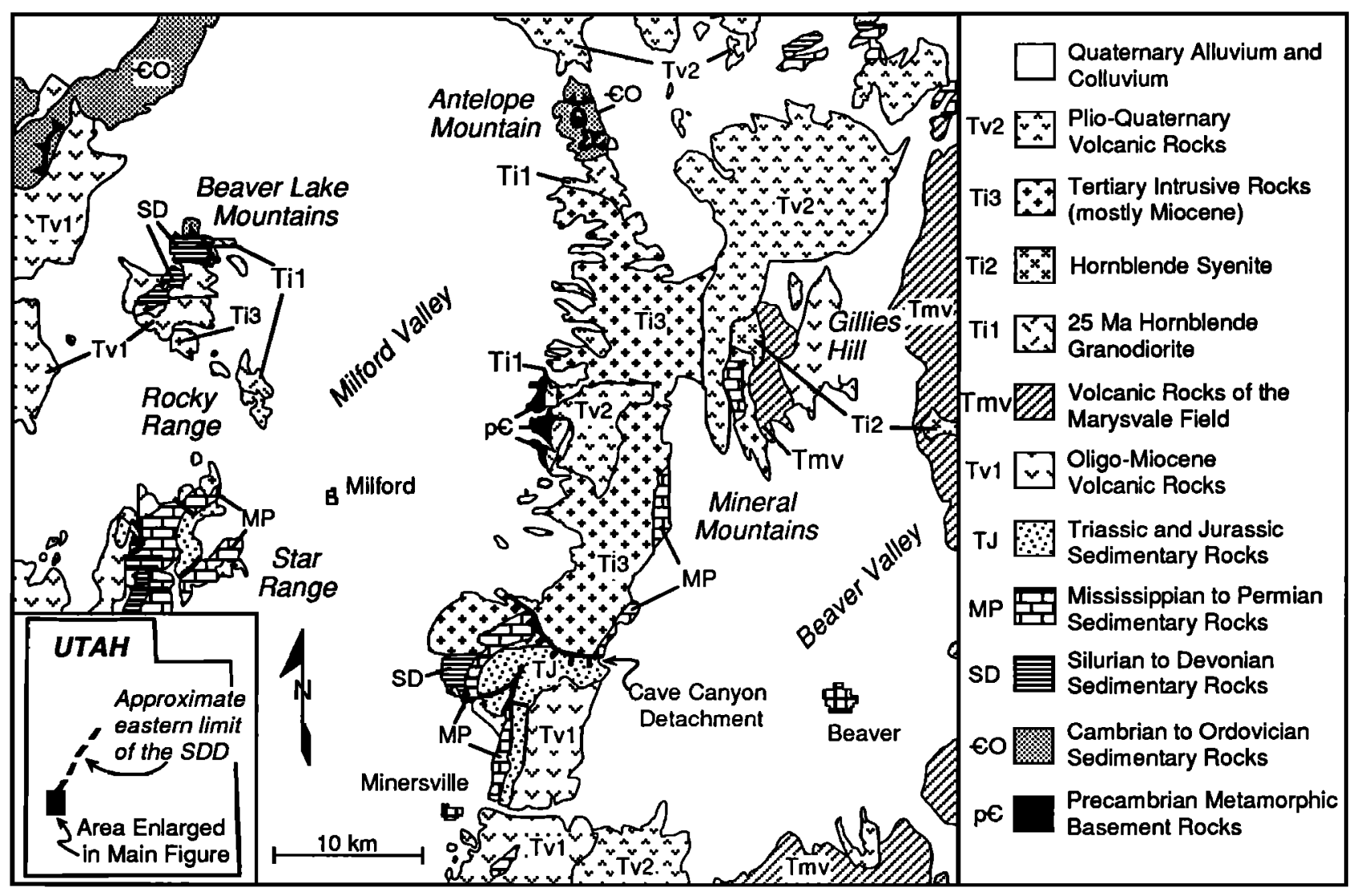

Fig. 1. General geology of the Mineral Mountains and the surrounding region, compiled from Hintze [1980], with minor revisions after Coleman [1991] and J. D. Walker and J. M. Bartey (unpublished mapping, 1990, 1991). Inset shows the location of the study area and the location of the eastem limit of the Sevier Desert detachment as it is mapped in the subsurface. The eastem limit of the map includes the edge of the Marysvale volcanic field which lies within the Colorado Plateau. Unit Tv1 includes voluminous Oligocene ignimbrites of the Marysvale volcanic field, and unit Tv2 at the northem end of the map includes the southernmost tip of the Twin Peaks volcanic field. 
nite and low-silica granite comprising greater than $80 \%$ of the exposed phases [Nielson et al., 1978, 1986; Sibbett and Nielson, 1980]. Field relations indicate that there is a progression toward intrusion of more silicic phases throughout the history of the batholith [Coleman, 1991]. Early (25 Ma) intrusive events are essentially $100 \%$ granodiorite whereas the main intrusive event (18-16 Ma) is characterized by early intrusion of quartz monzonite and syenite followed by intrusion of quartz-poor granite and subsequent intrusion of quartz-rich granite. Emplacement of each of these phases was coincident with apparently minor, but ubiquitous, gabbro intrusion. The youngest igneous activity exposed in the batholith ( $9 \mathrm{Ma}$ and Quaternary) is essentially bimodal basalt/ rhyolite dike emplacement and volcanism.

In general, the batholithic units are medium- to coarse-grained and are fresh at the mineral scale despite locally pervasive formation of grus. Coarse-grained units intruded as stocks whereas diabase and rhyolite are limited to dikes which vary from less than a meter to tens of meters thick. Monzonitic to granitic rocks comprise homblende, biotite, $\mathrm{K}$-feldspar, plagioclase, quartz assemblages, whereas gabbros to granodiorites comprise pyroxene, hornblende, plagioclase \pm biotite and quartz assemblages [Nielson et al., 1978]. All phases of the batholith contain abundant accessory sphene, as well as apatite, allanite and zircon. Most units, including diabases and gabbros, contain primary hormblende and biotite indicating that all phases of the batholith were hydrous. Alteration of most of the batholithic units is limited to minor chloritization of homblende, although locally more significant alteration is present.

Field data indicate that mixing and fractional melting of young intrusive units were important in the generation of the batholith. During the $18-\mathrm{Ma}$ intrusive event, diorite and granite were intruded together and underwent significant mixing. This mixing event generated regional variations (gradual changes over tens of kilometers) in the petrography and chemistry of the units involved and yielded an essentially continuous range in composition from diorite to granite. Such variations were noted by Nielson et al. $[1978,1986]$ and Sibbett and Nielson [1980], but were not attributed to mixing. Nine-Ma dikes also show mixing between mafic and felsic units; however, compositional variations generated during this mixing event occur on a local, rather than regional, scale.

In addition to magma-mixing features, the northern and western margins of the batholith contain extensive zones of migmatization. The leucosome of the migmatites is quartz monzonitic and characterized by large phenocrysts of K-feldspar, whereas the melanasome comprises biotite + plagioclase + sphene \pm homblende and zircon. Geochronologic data for the phases involved in migmatization, and for the migmatites themselves, suggest that anatexis of 25-Ma hornblende granodiorite occurred at $18 \mathrm{Ma}$ and generated a porphyritic biotite-hornblende monzonite [Coleman, 1991], indicating that remobilization of young crust was an important process in the generation of at least some of the phases of the batholith.

\section{Results}

\section{Major and Trace Element Geochemistry}

Twenty-six samples from the Mineral Mountains batholith and associated igneous rocks in adjacent ranges were analyzed for major oxide compositions by $\mathbf{X}$ ray fluorescence spectrometry (Tables 1 and 2). A subset of these samples was analyzed for rare earth element (REE) geochemistry by directly-coupled plasma (DCP) analysis (Table 3). Detailed descriptions of analytical methods are provided by Coleman [1991]. The data in Table 2

TABLE 1. Sample Descriptions and Locations

\begin{tabular}{|c|c|c|}
\hline ple & Field Description ${ }^{*}$ & on \\
\hline MM88-3 & (Mmg) thin granophyric dike in biotite-hombl & $38^{\circ} 21^{\prime} 47^{\prime \prime} \mathrm{N} ; 112^{\circ} 50^{\prime} 38^{\prime \prime}$ \\
\hline & & $03 " \mathrm{~N}$ \\
\hline & mblende monz & '44" N; \\
\hline MM88-7 & (Ma) & $38^{\circ} 21^{\prime} 10^{\prime \prime} \mathrm{N} ; 112^{\circ} 47^{\prime} 05^{\prime \prime} \mathrm{W}$ \\
\hline 8-8 & egn & "46'44" W \\
\hline $8-10$ & & •29'12" N; \\
\hline $8-12$ & (IN) & $38^{\circ} 30^{\prime} 48^{\prime \prime} \mathrm{N} ;$ \\
\hline MM88-13 & & $38^{\circ} 22 ' 25^{\prime \prime} \mathrm{N}$ \\
\hline 8-14 & & 2 '36" N; \\
\hline $8-17$ & nde & $802008 " N$ \\
\hline $8-18$ & nde $n$ & $2007 " \mathrm{~N}$ \\
\hline MM88-20 & & $9 ' 56 " \mathrm{~W}$ \\
\hline 88-21 & ende & $20^{\prime} 21^{\prime \prime} \mathrm{N} ;$ \\
\hline 3-22 & & $3106 " \mathrm{~W}$ \\
\hline 88-23 & tite-ho & $511^{\prime} 15^{\prime \prime} \mathrm{W}$ \\
\hline $3-24$ & ite & 5'37" N; \\
\hline-25 & & $38^{\circ} 26^{\prime} 03^{\prime \prime} \mathrm{N}$ \\
\hline 8-32 & de di & $25^{\prime} 13^{\prime \prime} \mathrm{N}$ \\
\hline -4 4 & & '13" N; \\
\hline & & '04" W \\
\hline $9-10$ & e-homblende monzonite & $99^{\prime} 35^{\prime \prime} \mathrm{W}$ \\
\hline $9-17$ & & $9^{\prime} 35^{\prime \prime} \mathrm{W}$ \\
\hline $9-18$ & & $935 " \mathrm{~W}$ \\
\hline $9-20$ & & $19^{\prime} 48^{\prime \prime} \mathrm{N} ;$ \\
\hline $9-27$ & . & $38^{\circ} 22^{\prime 2} 27^{\prime \prime} \mathrm{N} ; 1$ \\
\hline & & 7'36" W \\
\hline 39-36 & nble & $38^{\circ} 30^{\prime} 14^{\prime \prime} \mathrm{N}$ \\
\hline 9-37 & (Mbhg) biotit & $38^{\circ} 33^{\prime} 30^{\prime \prime} \mathrm{N} ; 112^{\circ} 49^{\prime} 05^{\prime \prime} \mathrm{W}$ \\
\hline & Mbhg) biotit & 4 48" W \\
\hline & & $45 " \mathrm{~W}$ \\
\hline 50 & 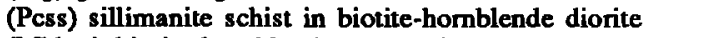 & $38^{\circ} 18^{\prime} 25^{\prime \prime}$ \\
\hline & Sol & $38^{\circ} 18^{\prime} 25^{\prime \prime} \mathrm{N} ; 112^{\circ} 54^{\prime} 54^{\prime \prime} \mathrm{W}$ \\
\hline & bas & $38^{\circ} 13^{\prime} 59^{\prime \prime} \mathrm{N} ; 112^{\circ} 50^{\prime} 21^{\prime \prime}$ \\
\hline
\end{tabular}

Unit designations (Mmg, Mbhm etc.) refer to map units of Coleman [1991]. 


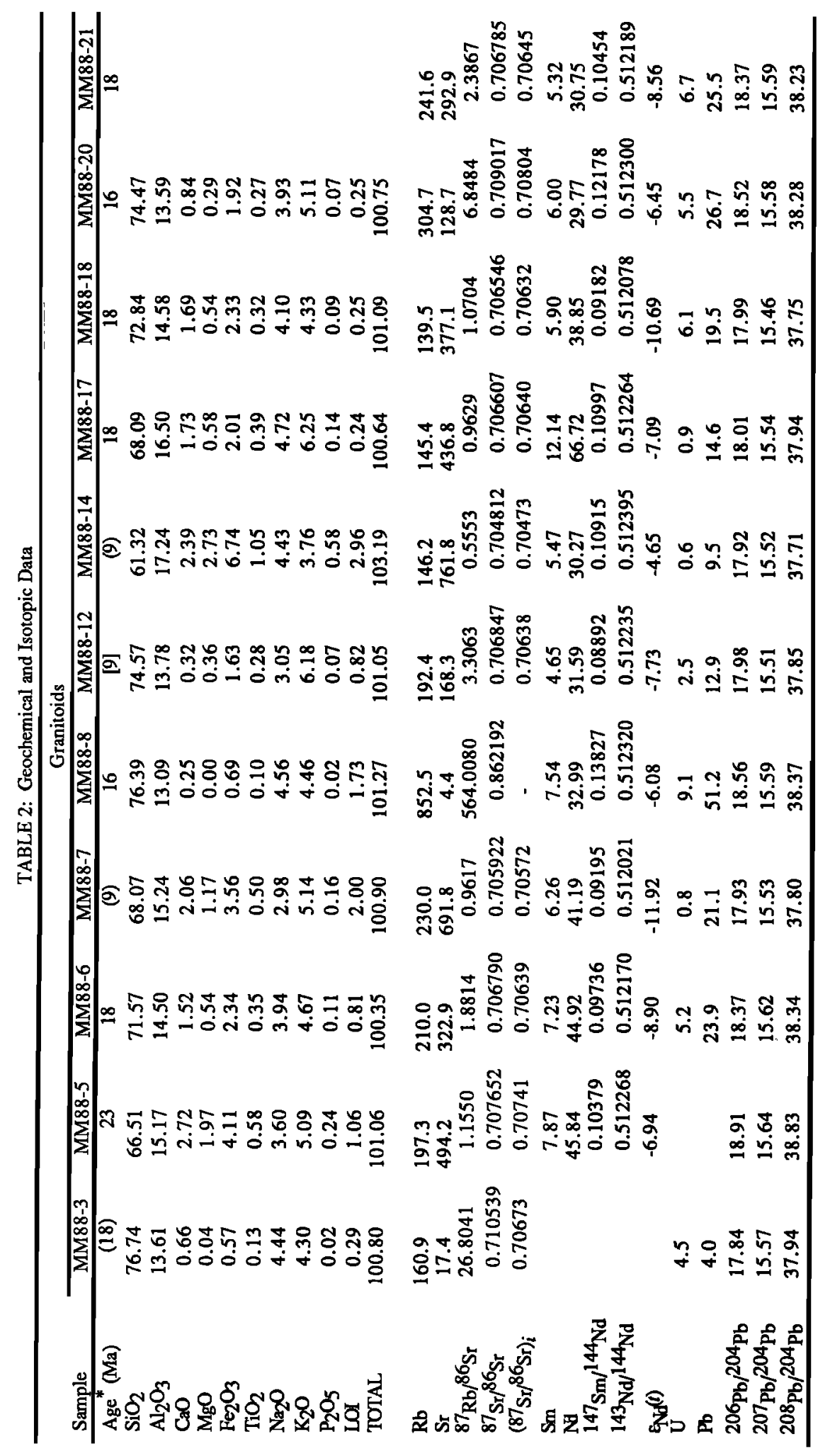




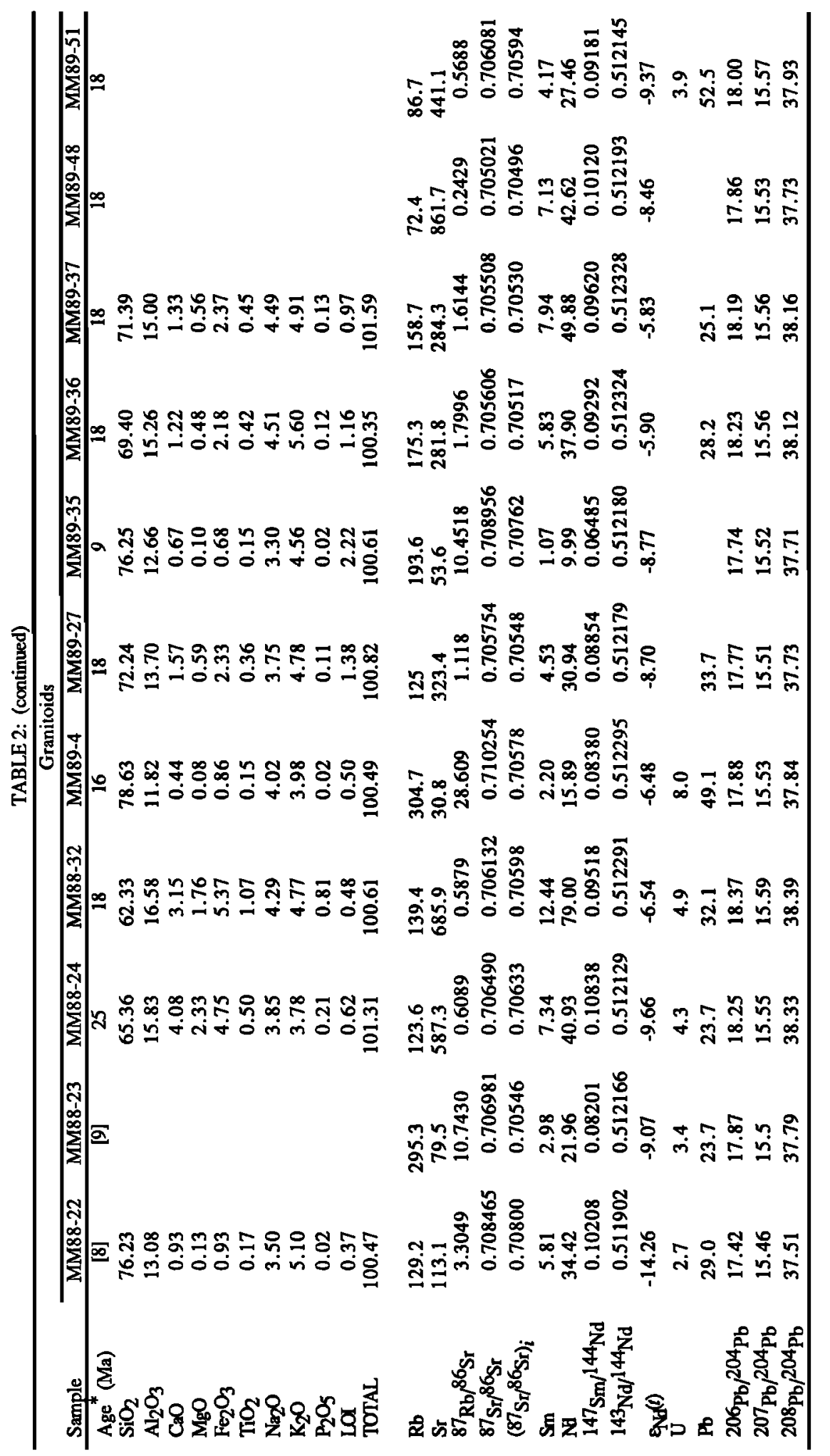




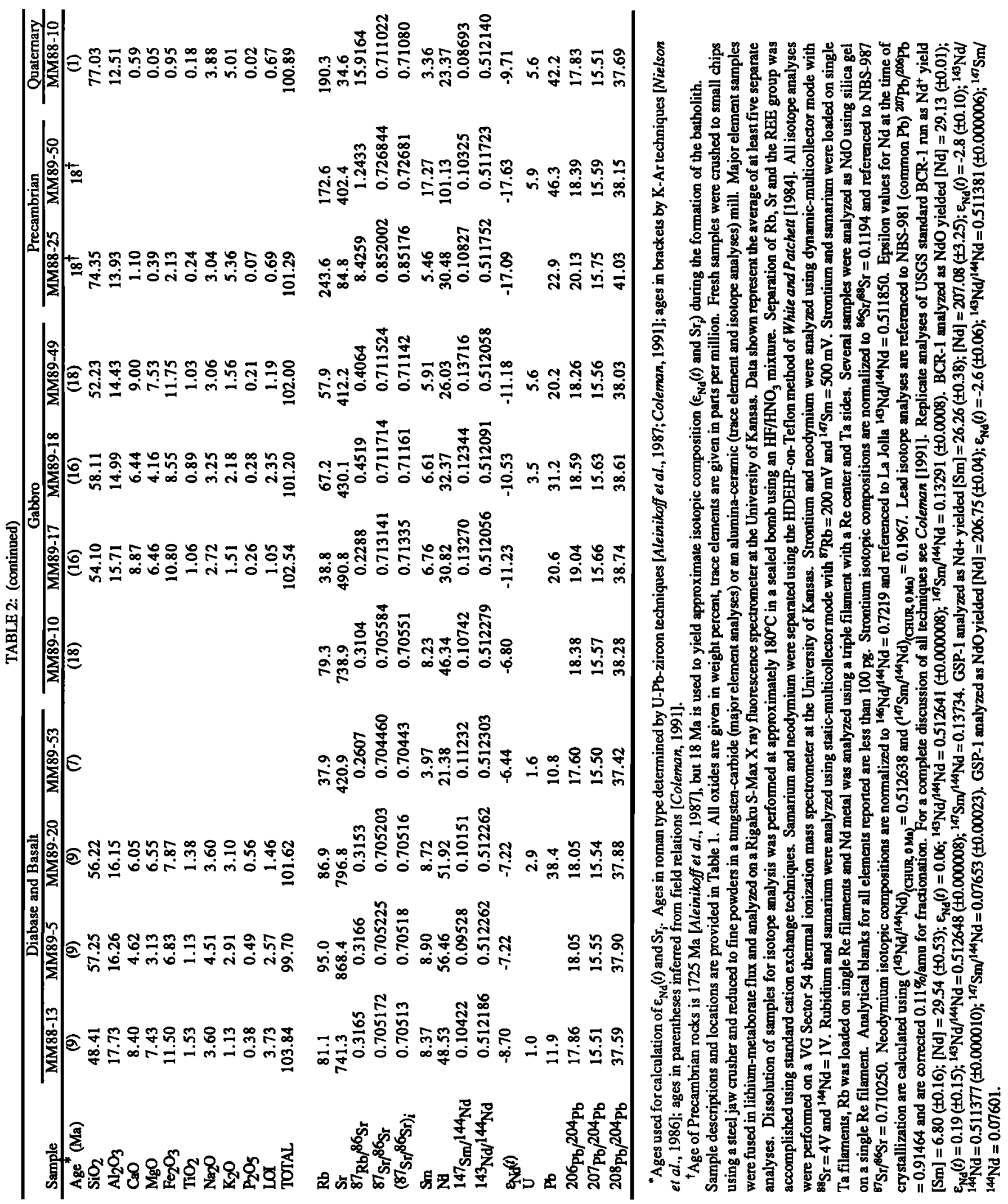




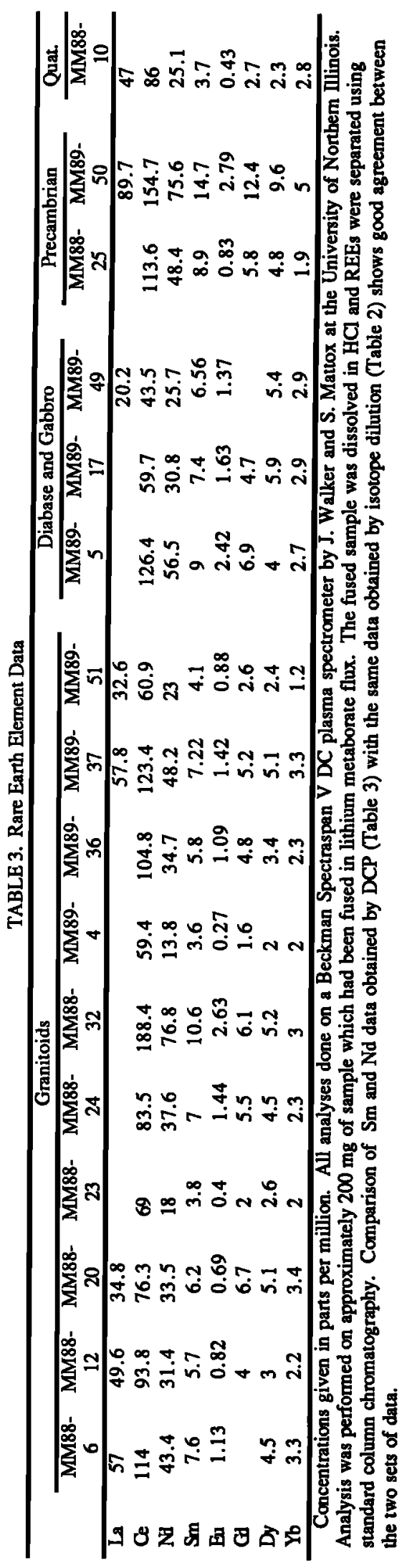

show a complete range in composition from 48 to 79 weight $\%$ $\mathrm{SiO}_{2}$, with the major phases of the batholith (biotite-homblende quartz monzonite, biotite-homblende granite and biotite granite) clustering between 68 to 79 weight $\% \mathrm{SiO}_{2}$. Several samples yielded totals greater than 102 weight $\%$, but are characterized by unusually high (2-4 weight \%) loss on ignition. Recalculation of the data on a volatile-free basis does not significantly alter the major oxide compositions.

All of the samples are moderately peraluminous to metaluminous, and show a well-defined calc-alkaline trend on a standard AFM diagram ( $\mathrm{Na}_{2} \mathrm{O}+\mathrm{K}_{2} \mathrm{O}: \mathrm{FeO}_{\text {total }}$ : $\mathrm{MgO}$ ). Samples which were designated as gabbros and diabases in the field have a wide range in bulk composition despite their similarities in petrography and occurrence. The most primitive mafic rock analyzed (MM88-13) can be classified as a basalt according to the scheme of Le Bas et al. [1986] and is transitional between an alkaline and high-alumina basalt. Major element compositions show significant scatter variably at high $\left(\mathrm{Na}_{2} \mathrm{O}, \mathrm{K}_{2} \mathrm{O}\right)$ and low $\left(\mathrm{Al}_{2} \mathrm{O}_{3}, \mathrm{TiO}_{2}\right.$, $\mathrm{Na}_{2} \mathrm{O}, \mathrm{P}_{2} \mathrm{O}_{5}$ ) silica, precluding any simple mixing or fractionation scenario for the origin of the trends (Figure 2).

Chondrite-normalized rare earth element data (Table 3, Figure 3) show moderate enrichment in all of the REEs, and greater enrichments in light REEs (LREE) relative to heavy REEs (HREE). Precambrian wall rocks to the batholith are slightly more REE enriched than Tertiary rocks, and there is a general trend toward decreasing REE contents in more evolved (granitic and rhyolitic) rocks relative to the diabase. Gabbroic rocks have significant depletion in REEs relative to the diabase, consistent with their marked deviation in major oxide chemistry as well. Most of the units analyzed have negative Eu anomalies, including very minor anomalies in the gabbros. Of the Tertiary units analyzed, only the diabase and one sample of biotite-homblende monzonite do not have Eu anomalies. In addition to Eu anomalies, granitic samples have marked depletion of middle REEs (MREE; Nd-Dy) relative to both the mafic rocks and the Precambrian wall rocks.

\section{Isotope Data}

Thirty-three samples from the Mineral Mountains and surrounding ranges were analyzed for $\mathrm{Pb}, \mathrm{Sr}$ and $\mathrm{Nd}$ isotopic compositions (Table 2, Figures 4 and 5). A discussion of analytical methods, normalization factors, reported analyses for standards and blank levels is provided at the bottom of Table 2 and by Coleman [1991]. Initial Sr ratios and $\varepsilon_{\mathrm{Nd}}(t)$ values were calculated using the best estimates for the ages of individual Tertiary samples, and $18 \mathrm{Ma}$ for Precambrian rocks in order to show the isotopic composition of the basement during the main phase of Tertiary magmatism.

There are no obvious correlations between major or trace element chemistry and isotopic composition in the data in Tables 2 and 3. Generally, the mafic and felsic rocks from the Mineral Mountains have indistinguishable $\mathrm{Pb}$ isotopic compositions. The Tertiary rocks have considerably less radiogenic $\mathrm{Pb}$ than the exposed Precambrian gneiss but have $\mathrm{Pb}$ isotopic compositions similar to the Precambrian sillimanite schist. Samples from the Mineral Mountains batholith have ${ }^{206} \mathrm{~Pb} / 204 \mathrm{~Pb}$ and ${ }^{208} \mathrm{~Pb} / 204 \mathrm{~Pb}$ comparable to other rocks from within $\mathrm{Pb}$ province Ib of Zartman [1974]. All of the data considered together define a poorly constrained $\mathrm{Pb}-\mathrm{Pb}$ age of $1760 \pm 280 \mathrm{Ma}$, consistent with the age of the exposed basement [Aleinikoff et al., 1987, $1725 \mathrm{Ma}$ ]; however, Tertiary samples considered alone define a much older age of $1870 \pm 380 \mathrm{Ma}$.

On the basis of their elevated $207 \mathrm{~Pb} / 204 \mathrm{~Pb}$ ratios relative to $206 \mathrm{~Pb} / 204 \mathrm{~Pb}$ ratios, Stacey and Hedlund [1983] and Wooden et al. [1988] argued that $\mathrm{Pb}$ from galenas in the Milford area had an 

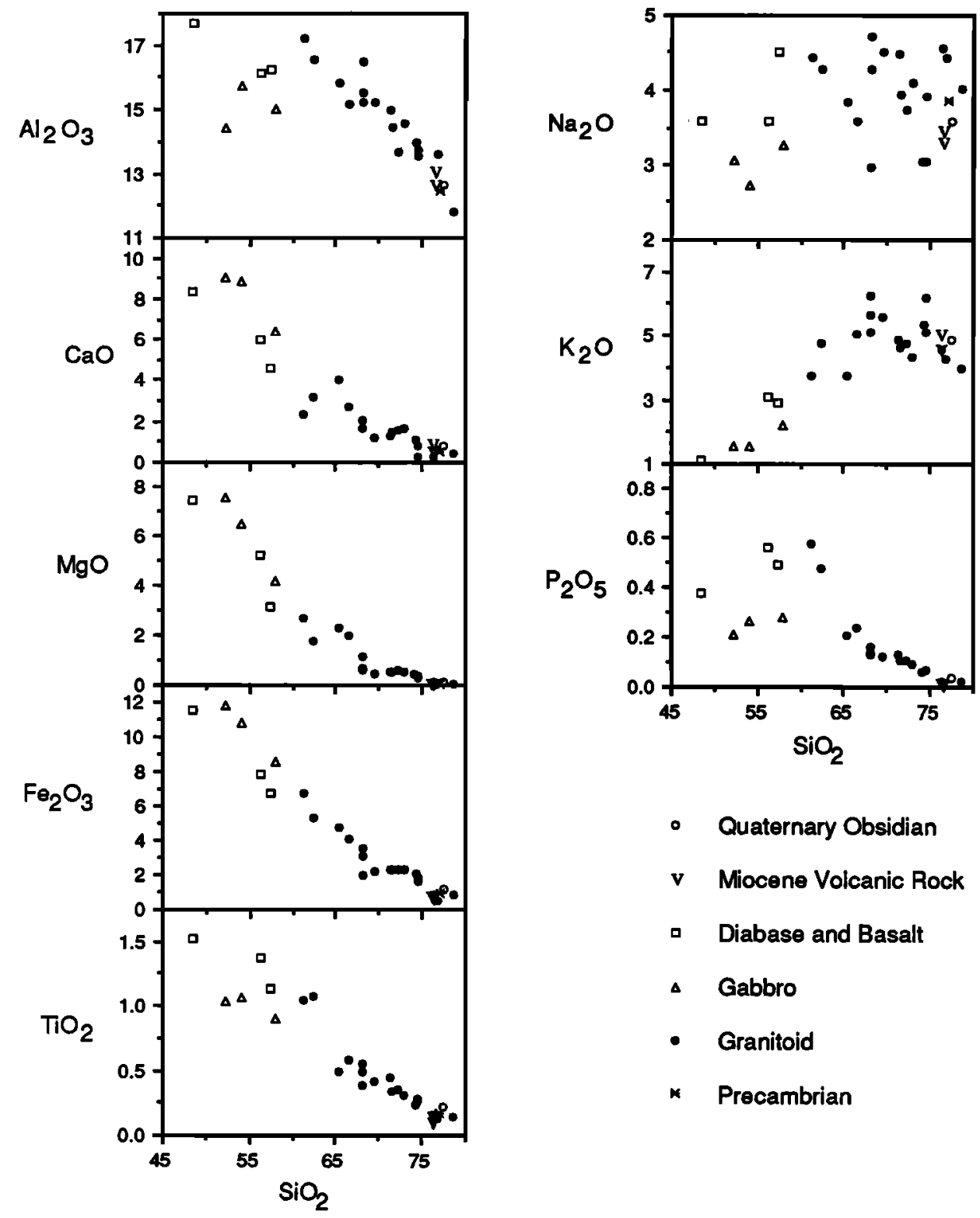

- Quaternary Obsidian

v Miocene Volcanic Rock

- Diabase and Basalt

$\triangle$ Gabbro

- Granitoid

* Precambrian

Fig. 2. Major element variation for the Mineral Mountains batholith. Plot symbols are as described in the figure.

Archean component. The data for Tertiary rocks from the Mineral Mountains lie on or below the $\mathrm{Pb}$ evolution curve of Stacey and Kramers [1975] (Figure 4a), and therefore there is no evidence for an Archean component in their source. This suggests that the $\mathrm{Pb}$ in the batholithic rocks of the Mineral Mountains was not derived from the same source as the $\mathrm{Pb}$ from the galenas, which Stacey and Hedlund [1983] interpreted to be Proterozoic crust. Furthermore, $\mathrm{Pb}$ from the Tertiary units in the Mineral Mountains plot below the orogene curve of Zartman and Doe [1981] (Figure 4a), which, according to the model of these authors, indicates that the rocks have little or no upper crustal component.

The overall variations in ${ }^{87} \mathrm{Sr}^{86} \mathrm{Sr}_{i}$ and $\varepsilon_{\mathrm{Nd}}(t)$ for samples from the Mineral Mountains batholith are quite large (0.70443 to 0.85176 and -4.65 to -17.63 , respectively); however, most of the Tertiary samples, including all of the granites and diabases, fall within a much narrower range $(0.7051$ to 0.7064 and -6 to -10 , respectively; Table 2, Figure 5). The isotopic compositions of the granites and diabases are significantly different than those of the exposed Precambrian basement rocks analyzed, whereas data for most gabbroic rocks and young volcanic rocks are notably shifted away from the main cluster of data for Miocene rocks tow ard wall rock isotopic compositions. Exclusive of these gabbro and volcanic rock samples, the $\mathrm{Pb}, \mathrm{Sr}$ and $\mathrm{Nd}$ isotopic compositions obtained for samples ranging in composition from diabase to granite are similar to those reported from elsewhere in the Basin and Range province for enriched mantle [cf. Fitton et al., 1988, 1991; Farmer et al., 1989; Menzies, 1989] (Figure 5a).

\section{Discussion}

Examination of the chemical and isotopic data in Tables 2 and 3 reveals that no simple mantle-crust mixing or fractionation (fractional crystallization or fractional melting) scenario can account for the trends. However, several fundamental observations can be made: (1) with one exception, gabbroic rocks are dramatically shifted in both bulk composition and isotopic composition away from diabases and granites, (2) several young volcanic rocks (9-1 Ma) are isotopically distinct from Miocene intrusive rocks, 


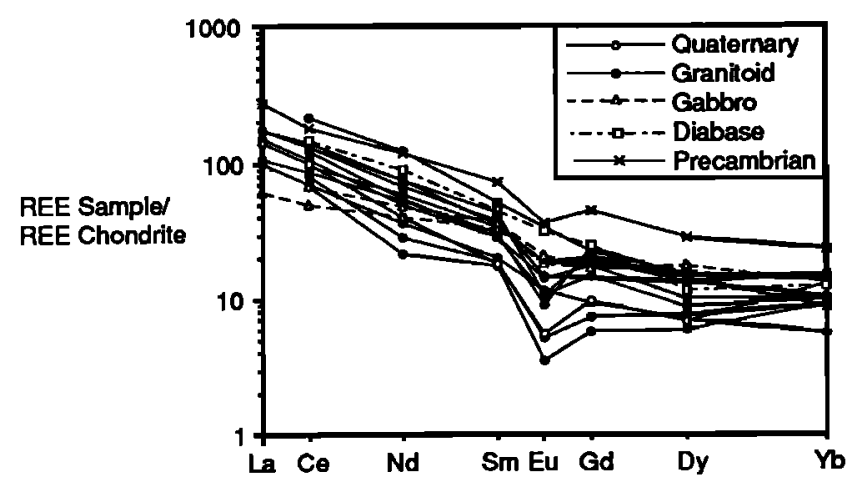

Fig. 3. Chondrite-normalized REE data for the Mineral Mountains batholith. Plot symbols are as described in the figure.

(3) exclusive of most gabbros, Miocene intrusive rocks show relatively little isotopic variation despite a wide range in bulk geochemistry, and no coherent chemical-isotopic covariation(Figures 2,4 , and 5). In order to simplify discussion of the evolution of the batholith, the outliers in the data set (gabbros and young volcanic rocks), which coincidentally represent a volumetrically insignificant portion of the exposed batholith, will be discussed first.

\section{Origin of Large Ion Lithophile-enriched Gabbros and Young Volcanic Rocks}

Gabbros which were collected within a few meters ( $<1$ to $2 \mathrm{~m}$ ) of exposed Precambrian and Paleozoic rocks (MM89-17, 18 and 49) have the most radiogenic $\mathrm{Sr}$ and $\mathrm{Pb}$, and the least radiogenic $\mathrm{Nd}$ among Tertiary intrusive rocks sampled in this study. These three gabbros also account for most of the scatter at the low-silica end of the major element plots, are significantly less $\mathrm{Sr}$ - and $\mathrm{Nd}$-rich, and have approximately 2 times the $\mathrm{Pb}$ concentration, relative to other mafic rocks analyzed. The proximity of these gabbros to exposed pre-Tertiary units and the shift in their isotopic compositions away from other Tertiary mafic and felsic rocks toward large ion lithophile (LIL)-enriched sources, suggests that these differences may be due to contamination by pre-Tertiary wall rocks. However, the REE pattems of the gabbros can not be reproduced by simple mixing with Proterozoic rocks analyzed, and some assimilation-fractionation process must be invoked to account for their chemical characteristics. The small negative Eu anomaly and LREE depletion in the gabbros is consistent with removal of plagioclase during crystallization. Altematively, field data cited above indicate that the chemistry of the gabbros should be affected by mixing with the Miocene granites which are also characterized by LREE and Eu depletion.

A monzonitic sample (MM89-51) which was collected adjacent to $(<1 \mathrm{~m})$ and is commingled with gabbro MM89-49 has significantly less radiogenic $\mathrm{Sr}$ and $\mathrm{Pb}$ and more radiogenic $\mathrm{Nd}$ than the gabbro, and is isotopically indistinguishable from other Tertiary granitic rocks in the range. Also, a gabbro collected approximately $5 \mathrm{~km}$ from the nearest exposed pre-Tertiary rocks (MM89-10) is isotopically indistinguishable from most other Tertiary mafic and felsic rocks. These relations suggest that whereas mixing with Miocene granites may have resulted in variable major element chemistry, small Eu anomalies, and depressed LREE concentrations among the gabbros, the radiogenic $\mathrm{Sr}$ and $\mathrm{Pb}$, and nonradiogenic $\mathrm{Nd}$ of gabbros collected near exposed pre-Tertiary units must reflect interaction with those units. Contamination by pre-Tertiary units undoubtedly altered the bulk

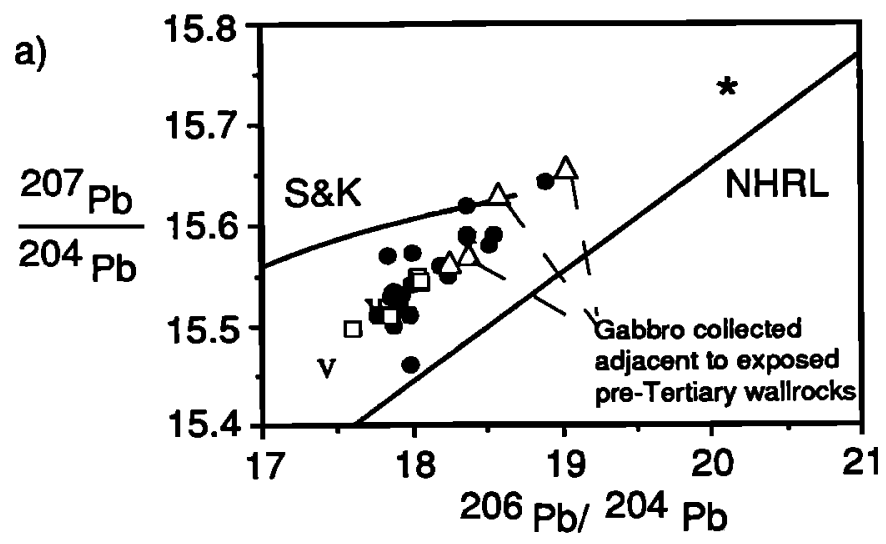

b)

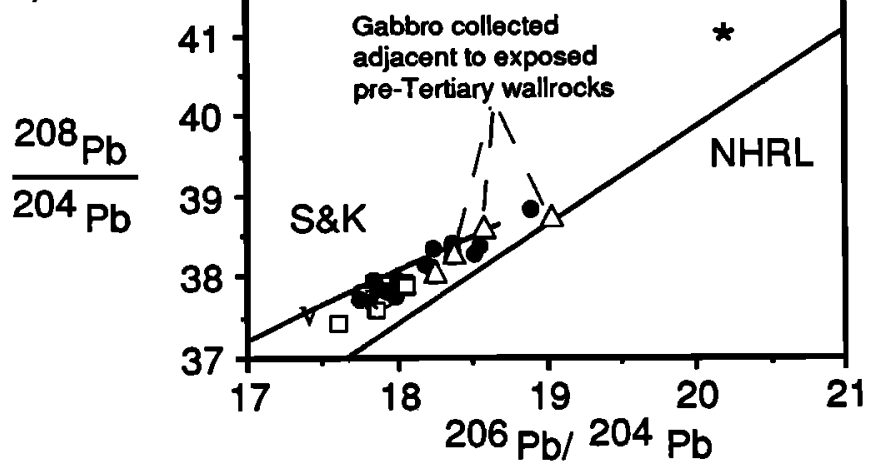

Fig. 4. $\mathrm{Pb}$ isotopic variation for the Mineral Mountains batholith. Plot symbols are as described in Figure 2 . S\&K = two-stage model Pb evolution of Stacey and Kramers [1975] and is approximately equivalent to the "orogene" curve of Zartman and Doe [1981]; NHRL = northem hemisphere reference line of Hart [1984].

chemistry of the gabbros as well; thus these gabbros probably reflect a complex variety of open-system effects.

Other than the gabbros, the only samples which have a significant shift away from the cluster of data in Figure 5 are an altered andesite dike, a Miocene rhyolite flow and Quaternary rhyolitic obsidian. The major oxide compositions of these samples plot along trends defined by other rocks from the batholith. The feldspar and groundmass of the andesite experienced extreme kaolinitization and sericitization, and it is possible that the relatively nonradiogenic ${ }^{143} \mathrm{Nd} /{ }^{144} \mathrm{Nd}$ of the andesite is the result of this dueteric alteration. Whereas the $\mathrm{Pb}$ isotopic compositions of the andesite and obsidian are comparable to other samples in this study, the $\mathrm{Pb}$ isotopic composition of the Miocene rhyolite is the least radiogenic $\mathrm{Pb}$ among samples analyzed from the Mineral Mountains. The rhyolite is also characterized by the highest ${ }^{208} \mathrm{~Pb} / 206 \mathrm{~Pb}$ ratio among samples analyzed, suggesting that it interacted with a lower crustal source characterized by low U-Th/ $\mathrm{Pb}$ but high $\mathrm{Th} / \mathrm{U}$ (see discussion below). The relatively radiogenic $\mathrm{Sr}$ and nonradiogenic $\mathrm{Nd}$ isotopic compositions of the Quaternary obsidian suggest that it may have interacted with upper crustal rocks similar to those which contaminated the gabbros. The obsidian is also characterized by a significant depletion in MREEs and a negative Eu anomaly which may be generated by plagioclase and sphene fractionation or interaction with the Miocene batholith which it erupted through. Alternatively, as discussed below for the Miocene portions of the batholith, the obsidian could obtain its REE characteristics through anatexis of the older Miocene intrusive rocks which are also characterized by 

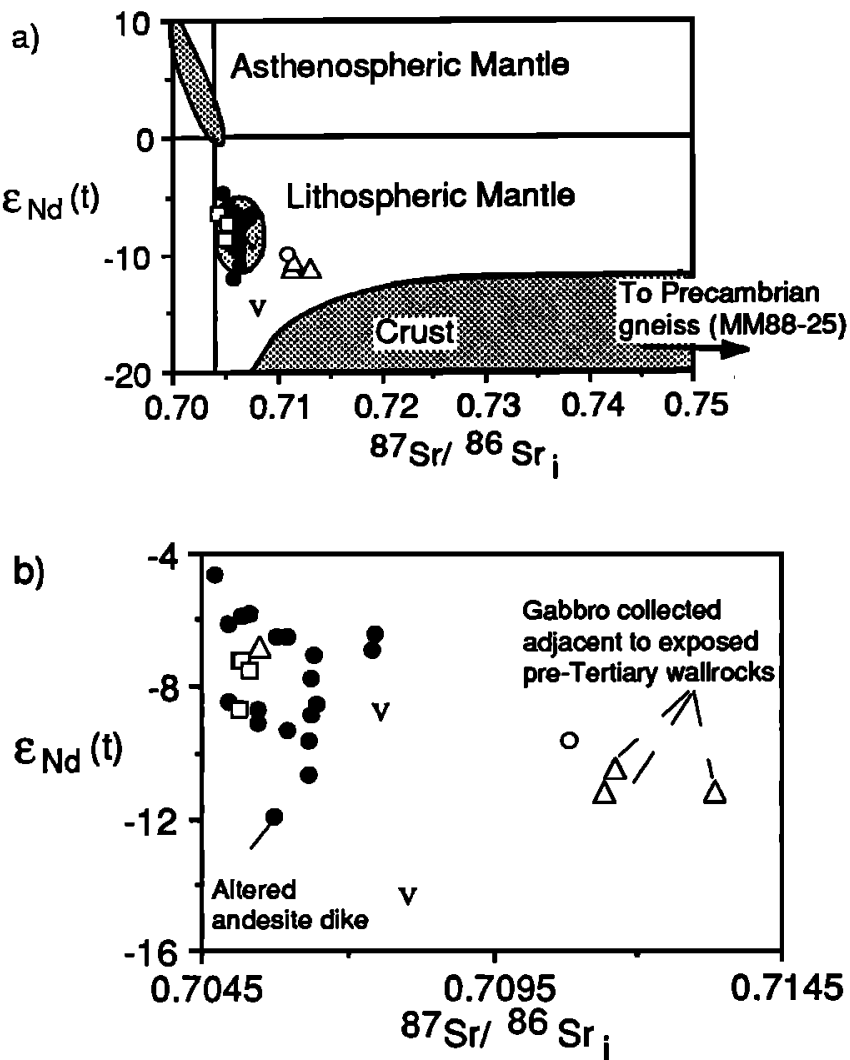

Fig. 5. Sr-Nd isotopic variation for the Mineral Mountains batholith. Plot symbols are as described in Figure 2. Figure $5 b$ is an enlargement of the data cluster in Figure $5 a$. Fields for mantle compositions are approximated from values reported for the Basin and Range province [cf. Fitton et al., 1988, 1991; Farmer et al., 1989; Menzies, 1989]. Field for preMiocene crust includes Precambrian, Mesozoic and early Tertiary crustal isotopic compositions (including analysis of exposed wall rocks to the batholith from this study) and extends beyond the limits of this figure [Kistler and Peterman, 1978; Leeman, 1982; Farmer and DePaolo, 1983, 1984; Bennett and DePeolo, 1988; Gans et al., 1989; Wright and Wooden, 1991]. Values for crust are present-day values or values back-calculated to $18 \mathrm{Ma}$ in order to represent the isotopic composition of crustal reservoirs which may have interacted with magmas during the generation of the batholith.

MREE depletions and negative Eu anomalies. This possibility is consistent with the Quatemary unit being among the most evolved rocks analyzed.

\section{Origin of Miocene Intrusive Rocks}

Excluding the samples discussed above, the remaining samples analyzed, including rocks which range from diabase and gabbro to rhyolite and granite, display coherent major oxide (with the exception of $\mathrm{Na}_{2} \mathrm{O}$ ) and $\mathrm{REE}$ trends, and have limited isotopic variability. These rocks comprise well over $95 \%$ of the exposed Tertiary batholith. Major oxide variation diagrams (Figure 2) exhibit linear to slightly curvilinear trends, consistent with field data indicating that both fractional melting and magma mixing are important processes in batholith formation. Fractional melting alone should generate kinks in oxide trends as phases enter and leave the fractionating assemblage, whereas two-component mixing alone should generate straight lines between end-members. Combined melting and mixing can generate the observed trends if melting moves liquids along one vector and subsequent mixing moves them along a different vector. The variable presence of biotite, plagioclase and homblende in the restitic portions of the migmatite allows for great flexibility in melting vectors. Recognition in the field that both fractional melting and mixing may affect the same unit (for example, the leucosome of the migmatite is mixed with a coeval gabbro) make it difficult to constrain the relative effects of any of these processes on the basis of major oxide data. Therefore we stress only that the trends observed are consistent with the field observations.

The REE patterns of the Tertiary batholith show very regular trends toward more negative Eu anomalies and more substantial MREE depletion with increasing silica. These trends can be reproduced by increasing fractionation of plagioclase (Eu anomaly), homblende and sphene (MREE depletion). Field evidence for fractional melting, and the presence of plagioclase, homblende and sphene in restitic portions of the migmatite can therefore account for the observed REE patterns. Either mixing between extremely depleted granitic magmas and undepleted mafic magmas, or progressive depletion of Eu and MREEs through a series of stepwise partial melting events could account for the intermediate REE compositions of intermediate composition rocks.

Fractional melting and magma mixing can also account for the isotopic data for the batholith. Field evidence for melting $25 \mathrm{Ma}$ granodiorite (such as MM88-24) to yield $18 \mathrm{Ma}$ biotite-hornblende monzonite (such as MM88-6, 18, 21 and MM89-51) explains the remarkable similarity in the $\mathrm{Pb}, \mathrm{Sr}$ and $\mathrm{Nd}$ isotopic compositions of these rocks (Table 2). Furthermore, mixing between isotopically similar $18 \mathrm{Ma}$ gabbro (such as MM89-10) and granite (such as MM89-27, 36 and 37) produces a wide range in bulk and REE compositions, and little variability in isotopic composition (Table 2). As discussed below, minor contamination by pre-Tertiary wall rock can account for the isotopic variability observed, but isotopic data seem to require relatively "closed system" behavior for generation of the Miocene batholith. That is, isotopic data are consistent with field, major oxide and REE data which indicate that the dominant processes controlling the chemical evolution of the batholith are magma mixing between isotopically similar end-member compositions in the batholith, and partial melting of older parts of the batholith, with little involvement of pre-Tertiary crust.

Alternatively, the batholith could represent fairly uniform mixtures of mantle with significant volumes of pre-Tertiary crustal material. This model could account for the observed major oxide variation and the REE pattems if a suitable crustal contaminant existed (not identified in the limited sampling of pre-Tertiary rocks in this study), or if assimilation/fractional-crystallization (AFC) processes involving fractionation of homblende, plagioclase and sphene were invoked. Fractional crystallization cannot be dismissed by the ehemical and isotopic data presented here. However, because Miocene migmatites are documented in the field area [Coleman, 1991], and cumulate phases have not been identified in this or any previous study of the batholith, mixing and fractional melting, rather than fractional crystallization, are preferred as the mechanisms responsible for generating the observed chemical and isotopic trends. The question of involvement of preTertiary crust can only be addressed by examining potential sources of the mafic and felsic rocks using isotopic data and modeling the evolution of the complex within limits imposed by these data.

\section{Origin of Isotopic Variation in Mafic Rocks}

The similarity in the isotopic compositions of the basalt, diabase and gabbro collected away from exposed basement rocks in this study suggest that they were all derived from the same source. On the basis of the isotopic composition of the mafic 
rocks, this source is interpreted to be lithospheric mantle identified in previous studies of $B$ asin and Range magmatism (Figures 4 and 5a) [Fitton et al., 1988, 1991; Farmer et al., 1989; Menzies, 1989]. There are several important alternative interpretations for the source of the mafic rocks. Origin in the asthenospheric mantle followed by crustal contamination is the most obvious and may be supported by petrographic data and major oxide compositions which indicate that some of the diabases are contaminated by more silicic material. However, as discussed above, gabbros which were collected adjacent to pre-Tertiary rocks and have bulk compositions similar to the diabases show significant shifts in $\mathrm{Sr}$ and $\mathrm{Pb}$ concentrations and isotopic compositions away from those of the diabases toward upper crustal isotopic compositions (Figures 4 and 5). This is best explained if the isotopic and bulk composition of the diabases was altered by interaction with the Miocene granites which they intrude rather than LIL-enriched pre-Tertiary crust. If this is true, models for the origin of the diabases through asthenosphere-crust mixing require nearly all (if not all) of the $\mathrm{Pb}$, $\mathrm{Sr}$ and $\mathrm{Nd}$ of the diabases to be crustal, which is unrealistic. Cryptic contamination of as thenosphere-derived liquids by mafic crustal rocks such as described by Glazner et al. [1991] and Glazner and Farmer [1992] may provide a more reasonable mantle/crust mixing scenario; however, this also fails to account for the limited isotopic variability of the diabases over the wide range in bulk compositions observed. The most straightforward argument is that the diabases were contaminated by silicic crust with isotopic compositions close to their own, and gabbroic rocks were contaminated by silicic crust characterized by radiogenic $\mathrm{Pb}$ and $\mathrm{Sr}$ and nonradiogenic Nd. Furthermore, there are no independent data from the Mineral Mountains (S. Mattox and D. S. Coleman, unpublished data, 1991) or anywhere along the Colorado Plateau/Basin and Range transition zone, supporting the presence of an asthenospheric mantle component in the magmas until the most recent volcanism (< 5 Ma [Fitton et al., 1988, 1991]). It seems unlikely that all of the older mafic rocks analyzed are asthenosphere-derived and crustally contaminated.

Alternatively, the mafic rocks need not be derived from the mantle at all and may be melts of a mafic lower crust. Many authors agree that ancient lower crustal rocks from the southwestern United States are characterized by a long-term enrichment of Th relative to U [cf. Zartman and Doe, 1981]. This generalization may be broadly applicable to granulite facies rocks [Rudnick et al., 1985; Wooden et al., 1988] and results in highly variable but elevated $208 \mathrm{~Pb} / 204 \mathrm{~Pb}$ ratios relative to $206 \mathrm{~Pb} / 204 \mathrm{~Pb}$ (high $208 \mathrm{~Pb}$ $206 \mathrm{~Pb}$ ) over time. Therefore if diabases from the Mineral Mountains were derived through anatexis of ancient lower crustal rocks they should lie above the evolution curve of Stacey and Kramers [1975] in Figure 4b. Clearly, this is not the case, but the possibility of derivation from young mafic lower crust can not be eliminated through interpretation of $\mathrm{Pb}$ isotopic data. Morse [1991] argues, however, that generation of a basaltic melt from the lower crust is implausible. He asserts that even if a basaltic melt could be derived from basaltic lower crust, the amount of mantle material advected to the crust necessary to yield a significant volume of basaltic liquid from it would completely overwhelm the crustal signature of the resultant magma.

\section{Origin of Isotopic Variation in Felsic Rocks}

The isotopic composition of the granitic rocks in the Mineral Mountains is indistinguishable from that of the mafic rocks, and different from that of the exposed basement in the range, indicating that the granites were not derived through anatexis of Precambrian upper crustal rocks. This is also supported by the differences in $\mathrm{Pb}$ isotope systematics between the Miocene granites and ore leads from the Mineral Mountains which were interpreted to be derived from Proterozoic upper and lower crust [Stacey and Hedlund, 1983; Wooden et al., 1988]. As with the origin of the isotopic composition of the mafic rocks, the isotopic compositions of the felsic rocks could be reproduced through asthenosphere-crust mixing, but this seems unlikely for many of the same reasons outlined above. Another alternative is that the granitic rocks were derived from anatexis of lower crust. On the basis of their elevated ${ }^{208} \mathrm{~Pb} / 204 \mathrm{~Pb}$ ratios, some of the igneous rocks exposed in the eastern Basin and Range province have been interpreted to represent lower crustal melts [Zartman, 1974], yet none of the reported isotopic data for Precambrian through Oligocene rocks are comparable to those for rocks in the Mineral Mountains (Figure 5a). Furthermore, as discussed above, the low $208 \mathrm{~Pb} / 206 \mathrm{~Pb}$ ratio of the rocks from the Mineral Mountains batholith argues against extensive involvement of Precambrian lower crustal rocks (Figure 4b) [Zartman and Doe, 1981; Rudnick et al., 1985; Wooden et al., 1988]. Perhaps one of the most likely choices for a crustal source for the Mineral Mountains batholith is Oligocene crust generated during the voluminous ash flow eruptions in this region. However, Sr isotopic data for these ash flows indicates that they are significantly more radiogenic than the rocks in this study [Leeman, 1982; Gans et al., 1989] and therefore are not suitable source material for the Mineral Mountains batholith.

The simplest explanation for the similarity between the isotopic compositions of mafic and felsic rocks is that the felsic rocks were derived from the mafic rocks. This explanation is particularly satisfying in light of the exposed Miocene migmatites in the batholith which demonstrate that at least some of the felsic rocks (quartz monzonite) were derived through anatexis of more mafic units (granodiorite). The variation in the isotopic compositions observed could be the result of minor upper crustal contamination and isotopic heterogeneity within the source.

\section{Model for the Evolution of the Mineral Mountains Batholith}

It is difficult to constrain the amount of mantle and crustal material present in the rocks from the Mineral Mountains batholith due to the variability in the bulk and isotopic compositions of possible crustal contaminants, and the variety of processes that affected the rocks. However, the isotopic compositions of all of the rocks from the Mineral Mountains can be modeled by limited mixing between enriched lithospheric mantle and crustal rocks (Figure 6). The end-member compositions on Figure 6 were fixed for the lithospheric mantle end-member and varied within the range of reported analyses of upper crustal rocks for the crustal end-member. Although variation of the model parameters within a reasonable range allows for all of the Mineral Mountains units to be derived through mixing between the two components, the wide range in possible end-member compositions limits the ability of the models to predict exact proportions of the end-members in any sample. End-members used in the models must be considered idealized compositions for what are variable sources and contaminants. The models shown in Figure 6 are consistent with mixing $30-40 \%$ crust into a lithospheric mantle-derived basaltic magma to generate the gabbros. The high proportion of crustal material modeled in the gabbros is consistent with their variable bulk compositions and REE patterns. The position of the granitic rocks relative to the gabbros on the mixing diagram, at lower proportions of crustal material, emphasizes the difficulty in deriving the granitic rocks through anatexis of old crust or mantle-crust mixing.

According to the model, several of the late volcanic rocks and Quaternary obsidian from the Mineral Mountains do have a sig- 

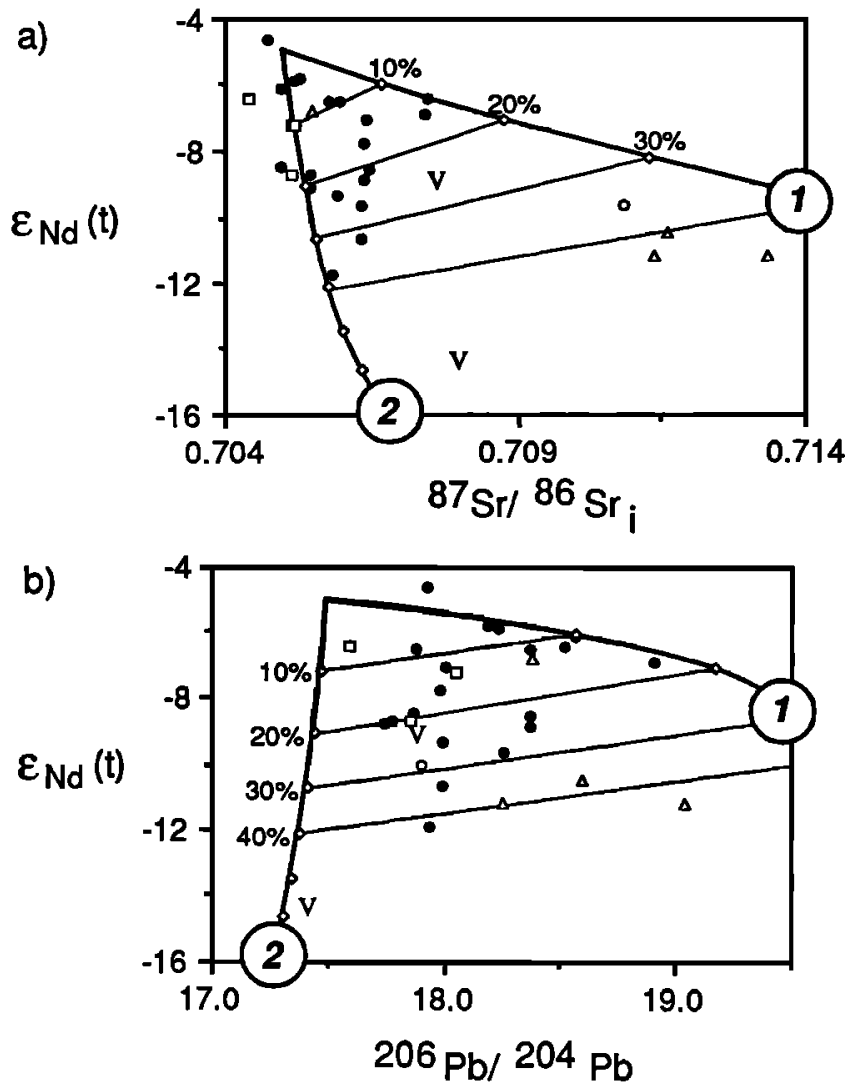

Fig. 6. Representative model mixing curves for $\mathrm{Nd}, \mathrm{Sr}$ and $\mathrm{Pb}$ calculated using the equations of Langmuir et al. [1978]. Plot symbols are as described in Figure 2. Mixing curve 1 is representative of mantle lithosphere interacting with a large ion lithophile (LIL)-enriched reservoir similar to reported analyses of local Precambrian upper crust, and curve 2 is representative of mantle lithosphere interacting with an LIL-depleted reservoir (lower crust?). Straight lines connect $10 \%$ intervals of points of equal mantle component along the two mixing curves. Parameters for the mixing curves are lithospheric mantle (all curves) - $\mathrm{eNd}=-5$; $[\mathrm{Nd}]=40$ ppm; $\left.{ }^{87} \mathrm{Sr} /{ }^{\beta 6} \mathrm{Sr}=0.705 ;[\mathrm{Sr}]=800 \mathrm{ppm} ;{ }^{206 \mathrm{~Pb}}{ }^{004} \mathrm{~Pb}=17.5 ; \mathrm{Pb}\right]=10 \mathrm{ppm}$. Crust Model $1-\mathrm{eNd}=-18 ;[\mathrm{Nd}]=30 \mathrm{ppm} ;{ }^{87} \mathrm{Sr} /{ }^{86} \mathrm{Sr}=0.850$; $[\mathrm{Sr}]=85$ $\mathrm{ppm} ;{ }^{206} \mathrm{~Pb} /{ }^{204} \mathrm{~Pb}=20.5 ;[\mathrm{Pb}]=50 \mathrm{ppm}$. Crust Model $2-\mathrm{eNd}=-18 ;[\mathrm{Nd}]$ $=70 \mathrm{ppm} ;{ }^{87} \mathrm{Sr} /{ }^{6} \mathrm{Sr}=0.708 ;[\mathrm{Sr}]=400 \mathrm{ppm} ;{ }^{206} \mathrm{~Pb} / 204 \mathrm{~Pb}=17.2 ;[\mathrm{Pb}]=10$ ppm.

nificant crustal component in their isotopic composition (Figure 6), suggesting that through time old crust may become more important in magma generation. This may occur because, although initially cold, the Precambrian crust quickly becomes hot enough to melt due to intrusion of mafic magmas. The observation that gabbros assimilated old crust, and initially, higher silica rocks did not, further supports the possibility that the Precambrian basement was initially too cold to become extensively involved in magmatism. Alternatively, crustal contamination may only be important in very shallow, subvolcanic, magma chambers in the region.

The most straightforward interpretation of the field, chemical and isotopic data for the Miocene intrusive rocks in the Mineral Mountains batholith is that the rocks represent juvenile material added to the crust from the enriched mantle during Miocene extension. On the basis of the field and geochronologic evidence for Miocene migmatization of latest Oligocene rocks [Coleman, 1991], fractional melting of young crust is envisioned as the mechanism for differentiation of the batholith. Although fractional crystallization or zone refining may have also played a role in the evolution of the magma system, as is interpreted for many other Tertiary igneous centers in the western United States which display isotope systematics similar to the Mineral Mountains batholith [cf. Halliday et al., 1984; Johnson, 1991; Johnson et al., 1989], we find no field or chemical evidence which require fractional crystallization.

We propose that the batholith may have evolved through a series of partial melting events, one of which is exposed in the range. According to this idea, a gabbro derived from melting of the lithospheric mantle, perhaps due to decompression during extension, is emplaced into the crust, and is subsequently melted during another intrusive event. If the gabbro is high in incompatible elements including potassium (as are the gabbros in the Mineral Mountains), melting may yield a granodioritic liquid. This granodiorite may then be melted to yield an even higher-silica unit, a quartz monzonite, or ultimately a high silica granite or rhyolite. This model is consistent with that of Huppert and Sparks [1988] for the evolution of calcalkaline granitic crust. Although existing experimental work on hydrous melting of rocks of basaltic composition indicates that liquids tend to be tonalitic and trondhjemitic [cf.Johnston, 1986; Johnston and Wyllie, 1988; Beard and Lofgren, 1991], data for melting high-K, amphibole-bearing mafic rocks, such as those in the Mineral Mountains, are not available and remain as an important test to the ideas presented here. Beard and Lofgren [1991] did generate a limited number of granodioritic melts in their experiments, and emphasized that the $\mathrm{Na} / \mathrm{K}$ of starting materials was reflected in melt compositions.

This model raises several important points regarding the evolution of the mantle in this part of the Basin and Range province. If the batholithic rocks in the Mineral Mountains were derived indirectly from the lithospheric mantle, their $\mathrm{Pb}-\mathrm{Pb}$ isochron age of approximately $1870 \mathrm{Ma}$ is consistent with the idea that the enriched mantle in the region may be Proterozoic [Menzies et al., 1983; Farmer et al., 1989]. This age (1870 Ma) is somewhat older than that of overlying crust, perhaps supporting a minor older crust component in the lithospheric mantle; however, on the basis of the low ${ }^{207} \mathrm{~Pb} / 206 \mathrm{~Pb}$ ratios of the rocks, this source is probably not Archean as suggested by Wooden et al. [1988]. Curiously, lithospheric mantle compositions reported by Wright and Wooden [1991] for Jurassic-Early Cretaceous rocks from the eastern Great Basin are nearly identical to those inferred for Tertiary rocks from the Basin and Range Province [Fitton et al., 1988, 1991; Farmer et al., 1989; Gans et al., 1989]. This implies that the isotopic composition of the lithospheric mantle has not evolved significantly since the Mesozoic, and because it is "enriched" mantle (high Rb, U and Th), it should have. A possible explanation for this paradox is that Mesozoic subduction depleted the enriched mantle in $\mathrm{Rb}, \mathrm{U}$ and Th, essentially "freezing" its isotopic composition during the Mesozoic.

Another feature of the Basin and Range mantle noted by Fitton et al. [1988, 1991], and supported by the data in this study, is that asthenospheric mantle sources were apparently not involved in early extension in this region. Fitton et al. [1988] argued that this indicated a passively sampled mantle; however, Fitton et al. [1991] later suggested that the overall pattern of magmatism throughout the Basin and Range province, and the late introduction of asthenospheric sources along the transition zone indicated an active upwelling asthenosphere plume. In particular, Fitton et

al. [1991] noted that lithospheric mantle sources were long-lived at the eastern and western margins of the Great Basin, relative to the central portions of the region. An alternative interpretation of these same observations is that the eastern and western margins of the Basin and Range province could represent the hanging wall and footwall, respectively, of a region deformed by an overall simple- 
shear mechanism [Farmer et al., 1989, Figure 1]. According to this model, lithospheric mantle is structurally removed in the central part of the extending orogen but remains intact, until thermally removed, along the margins. This may also explain the apparent lack of lithospheric mantle sources along the southern margin of the $B$ asin and Range, which is difficult to reconcile with the model of Fitton et al. [1991].

\section{Conclusions}

The Mineral Mountains record approximately $25 \mathrm{Ma}$ of intrusive and extrusive igneous activity which was largely contemporaneous with $B$ asin and Range extension. Field, chemical and isotopic data suggest that the processes controlling the evolution of the magma system were magma mixing and partial melting of young crust. These two processes combined to generate a wide variation in bulk chemistry with little variation in isotopic compositions. Minor addition of pre-Tertiary crust to a limited volume of the magmas resulted in significantly greater scatter in isotopic compositions. The ultimate source for all of the rocks in the Mineral Mountains is interpreted to be lithospheric mantle, and high-silica units are envisioned to be related to low-silica units through a series of partial melting events. Intermediate composition rocks may represent intermediate partial melting steps or mixtures of gabbro and granite. Thus the Mineral Mountains batholith is interpreted to represent juvenile granitic material added to the continental crust during extension.

The stepwise partial melting mechanism proposed here could operate very efficiently in extensional settings due to the rapid influx of magmas from the mantle which provide both great volumes of material to differentiate into high-silica crust, and the heat necessary for melting. Although the Mineral Mountains represent a relatively small volume system when compared to the large Tertiary ash flow sheets exposed in the western United States, the evidence for fractional melting in the Mineral Mountains suggests that partial melting of young crust may be a regionally important mechanism in the differentiation of isotopically homogeneous systems.

The results of this study suggest that extensional tectonics may be important in generating silicic crust with a significant young mantle component. This observation could help explain the similarity in mantle separation ages and crystallization ages of some of Proterozoic anorogenic granites. Furthermore, this investigation indicates that there may be a component of pure shear, as igneous inflation of the crust by the mantle, during Tertiary extension in this region of the Basin and Range province. Many authors have suggested that pure-shear extension may inflate the crust through voluminous intrusion of mafic liquids which remain under highly extended terranes. The results presented here indicate, however, that a large volume of the juvenile crust generated may be granitic in composition and calcalkaline in nature. There is no reason why the same mechanism should not have been active during extension throughout geologic time, raising the possibility that other exposures of granitic crust may be extensional, and that extension can be an important crust forming event.

Acknowledgments. This work was supported through National Science Foundation grant EAR-8904007 awarded to Walker, and by student research grants awarded to Coleman through the Geological Society of America and Sigma Xi. We wish to thank J.M. Bartley for insightful discussions in the field, C. Johnson and an anonymous reviewer for helpful reviews, and J. S. Miller and $M$. W. Martin for their discussions regarding this paper, and for reviewing an earlier version of this manuscript.

\section{REFERENCES}

Aleinikoff, J. N., D. L. Nielson, C. E. Hedge, and S. H. Evans, Geochronology of Precambrian and Oligocene rocks in the Mineral Mountains, south-central Utah, U.S. Geol. Surv. Bull., 1622, 1-12, 1987.

Allmendinger, R. W., J. W. Sharp, D. Von Tish, L. Serpa, L. Brown, S. Kaufman, and J. Oliver, Cenozoic and Mesozoic structure of the eastem Basin and Range province, Utah, from COCORP seismicreflection data, Geology, 11, 532-536, 1983.

Anderson, J. L., Proterozoic anorogenic plutonism of North America, in Proterozoic geology: Selected Papers From an International Proterozoic Symposium, Mem. 161, edited by L. G. J. Medaris et al., Pp. 133154, Geological Society of America, Boulder, Colo., 1983.

Barker, C. A., Upper-crustal structure of the Milford Valley and Roosevelt Hot Springs, Utah region, by modeling of seismic refraction and reflection data, M.S. thesis, 101 pp., Univ. of Utah, Salt Lake City, 1986.

Beard, J. S., and G. E. Lofgren, Dehydration melting and water-saturated melting of basaltic and andesitic greenstones and amphibolites at 1,3, and $6.9 \mathrm{~kb}$, J. Petrol., 32, 365-401, 1991.

Bennett, V., and D. J. DePaolo, Proterozoic crustal history of the westem United States as determined by neodymium isotopic mapping, Geol. Soc. Am. Bull., 99, 674-685, 1988.

Bickford, M. E., Formation of continental crust: Part 1. A review of some principles; Part 2. An application to the Proterozoic evolution of southem North America, Geol. Soc. Am. Bull., 100, 1375-1391, 1988.

Block, L, and L. H. Royden, Core complex geometries and regional scale flow in the lower crust, Tectonics, 9. 557-567, 1990.

Bohannon, R. G., Tectonic configuration of the western Arabian continental margin, southern Red Sea, Tectonics, 5, 477-499, 1986.

Bowring, S. A., T. B. Housh, and F. A. Podosek, Nd isotopic constraints on the evolution of Precambrian "anorogenic" granites from Missouri (abstract), Eos Trans. AGU, 72, 310, 1991.

Coleman, D. S., Geology of the Mineral Mountains batholith, Utah, Ph.D. thesis, 219 pp., Univ. of Kansas, Lawrence, 1991.

Condie, K. C., Petrogenesis of the Mineral Range Pluton, Southwestem Utah, M.A. thesis, 92 pp., Univ. of Utah, Salt Lake City, 1960.

Earl, F. N. Geology of the Central Mineral Range, Ph.D. thesis, 112 pp., Univ. of Utah, Salt Lake City, 1957.

Eichelberger, J. C., Andesitic volcanism and crustal evolution, Nature, 275, 21-27, 1978.

Evans, S. H., and T. A. Stevens, Rhyolites in the Gillies Hill-Woodtick Hill area, Beaver County, Utah, Geol. Soc. Am. Bull., 93, 1131-1141, 1982.

Farmer, G. L., and D. J. DePaolo, Origin of Mesozoic and Tertiary granite in the westem United States and implications for pre-Mesozoic crustal structure, 1, Nd and Sr isotopic studies in the Geocline of the northern Great Basin, J. Geophys. Res., 88, 3379-3401, 1983.

Farmer, G. L., and D. J. DePaolo, Origin of Mesozoic and Tertiary granite in the westem United States and implications for pre-Mesozoic crustal structure, 2, Nd and $\mathrm{Sr}$ isotopic studies of unmineralized and $\mathrm{Cu}$ - and Mo-mineralized granites in the Precambrian craton, J. Geophys. Res., 89, 10141-10160, 1984.

Farmer, G. L., F. V. Perry, S. Semken, B. Crowe, D. Curtis, and D. J. DePaolo, Isotopic evidence on the structure and origin of subcontinental lithospheric mantle in southem Nevada, J. Geophys. Res., 94, 7885$7898,1989$.

Fitton, J. G., D. James, P. D. Kempton, D. S. Ormerod, and W. P. Leeman, The role of lithospheric mantle in the generation of late Cenozoic basic magmas in the westem United States, J. Petrol., 29, 331-349, 1988.

Fitton, J. G., J. Dodie, and W. P. Leeman, Basic magmatism associated with late Cenozoic extension in the western United States: Compositional variations in space and time, J. Geophys. Res., 96, 13693-13711, 1991.

Gans, P. B., An open-system, two-layer crustal stretching model for the eastem Great Basin, Tectonics, 6, 1-12, 1987.

Gans, P. B., G. A. Mahood, and E. Schermer, Synextensional magmatism in the Basin and Range province: A case study from the eastem Great Basin, Spec. Pap. Geol. Soc. Am., 233, 53 pp., 1989.

Glazner, A. F., and G. L. Farmer, Production of isotopic variability in continental basalts by cryptic crustal contamination, Science, 255, 7274, 1992.

Glazner, A. F., G. L. Farmer, W. T. Hughes, J. L. Wooden, and W. Pickthom, Contamination of basaltic magma by mafic crust at Amboy and Pisgah Craters, Mojave Desert, Califomia, J. Geophys. Res., 96, 13673-13691, 1991.

Halliday, A. N., A. E. Fallick, J. Hutcinson, and W. Hildreth, A Nd, Sr and $O$ isotopic investigation into the causes of chemical and isotopic 
zonation in the Bishop Tuff, Califomia, Earth Planet. Sci. Lett., 68 , 379-391, 1984.

Hart, S., A large-scale isotope anomaly in the Southern Hemisphere mantle, Nature, 309, 753-757, 1984.

Hildreth, W., Gradients in silicic magma chambers: Implications for lithospheric magmatism, J. Geophys. Res., 86, 10153-10192, 1981.

Hintze, L. F., Geologic map of Utah, Utah Geol. and Miner. Surv., Salt Lake City, 1980.

Huppert, H. E., and R. S. Sparks, The generation of granitic magmas by intrusion of basalt into continental crust, J. Petrol., 29, 599-624, 1988.

Johnson, C. M., Large scale crust formation and lithosphere modification beneath Middle to Late Cenozoic calderas and volcanic fields, western North America, J. Geophys. Res., 96, 13485-13507, 1991.

Johnson, C. M., G. K. Czamanske, and P. W. Lipman, Geochemistry of intrusive rocks associated with the Latir volcanic field, New Mexico, and contrasts between evolution of plutonic and vol canic rocks, Contrib. Mineral. Petrol., 103, 90-109, 1989.

Johnson, C. M., P. W. Lipman, and G. K. Czamanske, H, O, Sr, Nd, and $\mathrm{Pb}$ isotope geochemistry of the Latir volcanic field and cogenetic intrusions, New Mexico, and relations between evolution of a continental magmatic center and modifications of the lithosphere, Contrib. Mineral. Petrol., 104, 99-124, 1990.

Johnston, A. D., Anhydrous P-T phase relations of near-primary highalumina basalt from the South Sandwich Islands, Implications for the origin of island arcs and tonalite trondhjemite series rocks, Contrib. Mineral. Petrol., 92, 368-382, 1986.

Johnston, A. D., and P. J. Wyllie, Constraints on the origin of Archean trondhjemites based on phase relationships of Nâk gneiss with $\mathrm{H}_{2} \mathrm{O}$ at 15 kbar, Contrib. Mineral. Petrol., 100, 35-46, 1988.

Kay, S. M., V. A. Ramos, C. Mpodozis, and P. Sruoga, Late Paleozoic to Jurassic silicic magmatism at the Gondwana margin: Analogy to the Middle Proterozoic in North America, Geology, 17, 324-328, 1989.

Kistler, R. W., and Z. E. Peterman, Reconstruction of crustal blocks of California on the basis of initial strontium isotopic compositions of Mesozoic granitic rocks, U.S. Geol. Surv. Prof. Pap., 1071, 17 pp., 1978.

Langmuir, C. H., R. D. Vocke, G. N. Hanson, and S. R. Hart, A general mixing equation with applications to Icelandic basalts, Earth Planet. Sci. Lett., 37, 380-392, 1978.

Le Bas, M. J., R. W. Le Maitre, A. Streckeisen, and B. Zanettin, A chemical classification of volcanic rocks based on the total alkali-silica diagram (Recommendations of the IUGS subcommission on the systematics of igneous rocks), J. Petrol., 27, 745-750, 1986.

Leeman. W.P., Tectonic and magmatic significance of strontium isotopic variations in Cenozoic volcanic rocks from the western United States, Geol. Soc. Am. Bull., 93, 487-503, 1982.

Liese, H. C., Geology of the Northem Mineral Range, Millard and Beaver Counties, Utah, M.S. thesis, 88 pp., Univ. of Utah, Salt Lake City, 1957.

Lipman, P. W., P. D. Rowley, H. H. Mehnert, S. H. J. Evans, W. P. Nash, and F. H. Brown, Pleistocene thyolite of the Mineral Range, Utah: Geothermal and archaeological significance, J. Res. U.S. Geol. Surv., 6, 133-147, 1978.

Menzies, M. A., Cratonic, circumcratonic and oceanic mantle domains beneath the westem United States, J. Geophys. Res., 94, 7899-7915, 1989.

Menzies, M. A., W. P. Leeman, and C. J. Hawkesworth, Isotope geochemistry of Cenozoic volcanic rocks reveals mantle heterogeneity below western USA, Nature, 303, 205-209, 1983.

Miller, E. L., P. B. Gans, and J. Garing, The Snake Range decollementAn exhumed mid-Tertiary ductile-brittle transition, Tectonics, 2, 239 . $263,1983$.

Morse, S. A., Basaltic magma from the crust is not a free option, Eos Trans. AGU, 72, 161, 1991.

Nelson, B. K., Proterozoic anorogenic volcanism in North America: Isotopic and trace element constraints on andesite and rhyolite genesis, St. Francois Mts., Missouri (abstract), JAVCEI International Volcanology Conference, Mainz, Abstr. Programs, 77, 1990.

Nelson, K. D., T. F. Zhu, A. Gibbs, R. Harris, J. E. Oliver, S. Kaufman, L. Brown, and R. A. Schweickert, COCORP deep seismic reflection profiling in the northem Sierra Nevada, California, Tectonics, 5, 321333, 1986.

Nielson, D. L., B. S. Sibbett, D. B. McKinney, J. B. Hulen, J. N. Moore, and S. M. Samberg, Geology of Roosevelt Hot Springs KGRA, Beaver County, Utah, Rep. 12, Earth Sci. Lab., Univ. of Utah Res. Inst., Salt Lake City, 1978.

Nielson, D. L., S. H. Evans, and B. S. Sibbett, Magmatic, structural, and hydrothermal evolution of the Mineral Mountains intrusive complex, Utah. Geol. Soc. Am. Bull., 97, 765-777, 1986.

Perry, F. V., W. S. Baldridge, and D. J. DePaolo, Role of asthenosphere and lithosphere in the genesis of late Cenozoic basaltic rocks from the Rio Grande rift and adjacent regions of the southwestern United States, J. Geophys. Res., 92, 9193-9213, 1987.

Price, D. E., and J. M. Bartley, Low- and high-angle faulting, southem Mineral Mountains, southwestem Utah, Geol. Soc. Am. Abstr. Programs, 22, 76, 1990.

Prodehl, C., Seismic refraction study of the western United States, Geol. Soc. Am. Bull., 81, 2629-2646, 1970.

Prodehl, C., Crustal structure of the westem United States, Geol. Soc. Am. Prof. Pap., 1034, 1-74, 1979.

Rudnick, R. L., S. M. McLennan, and S. R. Taylor, Large ion lithophile elements in rocks from high-pressure granulite facies terrains, Geochim. Cosmochim. Acta, 49, 1645-1655, 1985.

Sibbett, B. S., and D. L. Nielson, Geology of the central Mineral Mountains, Beaver County, Utah, Rep. 33, Earth Sci. Lab., Univ. of Utah Res. Inst., Salt Lake City, 1980.

Stacey, J. S., and D. C. Hedlund, Lead-isotopic compositions of diverse igneous rocks and ore deposits from southwestem New Mexico and their implications for early Proterozoic crustal evolution in the western United States, Geol. Soc. Am. Bull., 94, 43-57, 1983.

Stacey, J. S., and J. D. Kramers, Approximation of terrestrial lead isotope evolution by a two-stage model, Earth Planet. Sci. Lett., 26, 207-221, 1975.

Tegtmeyer, K. J., Regional variations in the Nd and Sr isotopic compositions of Tertiary peralkaline rhyolites from the Great Basin (abstract) Eos Trans. AGU, 71, 1682, 1990.

Von Tish, D. B., R. W. Allmendinger, and J. W. Sharp, History of Cenozoic extension in central Sevier Desert, west-central Utah, from COCORP seismic reflection data, Am. Assoc. Pet. Geol. Bull., 69, 1077-1087, 1985.

Walker, J. D., and J. M. Bartley, Subthrust conglomerate at Antelope Mountain, northem Mineral Mountains, Utah: Implications for thrust correlations and kinematics of extension, Geol. Soc. Am. Abstr. Programs, 22, 91, 1990.

Wernicke, B., The fluid crustal layer and its implications for continental dynamics, in Exposed Cross-Sections of the Continental Crust, edited by M. H. Salisbury and D. M. Fountain, pp. 509-544, Kluwer Academic, Netherlands, 1990.

Wernicke, B., G. J. Axen, and J. K. Snow, Basin and range extensional tectonics at the latitude of Las Vegas, Nevada, Geol. Soc. Am. Bull., 100, 1738-1757, 1988.

Wernicke, B. P., J. K. Snow, G. J. Axen, B. C. Burchfiel, K. V. Hodges, J. D. Walker, and P. L. Guth, IGC Field Trip T138: Extensional Tectonics in the Basin and Range Province Between the Southern Sierra Nevada and the Colorado Plateau, AGU, Washington, D. C., 1989.

White, W. M., and P. J. Patcheth, Hf-Nd-Sr isotopes and incompatible element abundances in island arcs: Implications for magma origins and crust-mantle evolution, Earth Planet. Sci. Lett., 67, 167-185, 1984.

Windley, B. F., Anorogenic magmatism and the Grenvillian orogeny, Can. J. Earth Sci., 26, 479-489, 1989.

Wooden, J. L., J. S. Stacey, K. A. Howard, B. R. Doe, and D. M. Miller, $\mathrm{Pb}$ isotopic evidence for the formation of Proterozoic crust in the southwestem United States, in Metamorphism and Crustal Evolution of the Western United States, edited by W. G. Emst, pp. 69-86, Prentice Hall, Englewood Cliffs, N. J., 1988.

Wright, J. E., and J. L. Wooden, New $\mathrm{Sr}, \mathrm{Nd}$, and $\mathrm{Pb}$ isotopic data from plutons in the northem Great Basin: Implications for crustal structure and granite petrogenesis in the hinterland of the Sevier thrust belt, Geology, 19, 457-460, 1991.

Zartman, R. E., Lead isotopic provinces of the westem United States and their geologic significance, Econ. Geol., 69, 792-805, 1974.

Zartman, R. E., and B. R. Doe, Plumbotectonics-The model, Tectonophysics, 75, 135-162, 1981.

D. S. Coleman, Department of Geology, University of North Carolina, Chapel Hill, NC 27599.

J. D. Walker, Department of Geology, University of Kansas, Lawrence, KS 66045 .

Recieved June 10, 1991; revised March 19, 1992; accepted March 19, 1992.) 